\title{
FAKTOR DEMOGRAFI, KONFLIK KERJA-KELUARGA, DAN KEPUASAN PERKAWINAN ISTRI BEKERJA
}

\author{
Fitri Meliani $^{\left.{ }^{*}\right)}$, Euis Sunarti ${ }^{2}$, Diah Krisnatuti ${ }^{2}$ \\ ${ }^{1}$ Program Studi IImu Keluarga dan Perkembangan Anak, Sekolah Pascasarjana, Institut Pertanian Bogor, \\ Bogor 16680, Indonesia \\ ${ }^{2}$ Departemen IImu Keluarga dan Konsumen, Fakultas Ekologi Manusia, Institut Pertanian Bogor, \\ Bogor 16680, Indonesia \\ *)E-mail: fitrim.1988@gmail.com
}

\begin{abstract}
Abstrak
Kepuasan perkawinan adalah elemen penting dalam kehidupan keluarga dan perkembangan pribadi. Keikutsertaan wanita dalam dunia tenaga kerja dan peran ganda mereka sebagai pencari nafkah dan pemelihara keluarga memiliki hubungan yang signifikan dengan kepuasan perkawinan. Penelitian ini bertujuan untuk melihat kepuasan perkawinan berdasarkan faktor demografi dan menganalisis pengaruh konflik kerja-keluarga terhadap kepuasan perkawinan. Desain penelitian ini adalah cross sectional. Contoh penelitian dipilih dengan teknik nonproportional stratified random sampling di Kecamatan Bogor Barat dan Bogor Tengah. Seratus dua puluh keluarga dengan suami-istri bekerja dipilih secara acak di lokasi penelitian. Hasil penelitian menunjukkan bahwa satu dari dua keluarga $(54,2 \%)$ memiliki level konfik kerja-keluarga yang sedang dan satu dari tiga $(39,2 \%)$ keluarga memiliki level kepuasan perkawinan yang tinggi. Hasil membuktikan bahwa kepuasan perkawinan dipengaruhi secara signifikan negatif oleh konflik kerja mengganggu keluarga. Temuan ini berarti bahwa semakin rendah konflik kerja mengganggu keluarga maka semakin tinggi kepuasan perkawinan. Faktor demografi yang memengaruhi kepuasan perkawinan adalah pendidikan istri. Berdasarkan penelitian ini diharapkan keluarga mampu menyusun suatu strategi yang dapat menjembatani peran di tempat kerja dan peran dalam rumah tangga sehingga dapat lebih puas mengenai perkawinannya.
\end{abstract}

Kata kunci: kepuasan perkawinan, konflik kerja-keluarga, peran ganda, suami-istri bekerja

\section{Demographic Factors, Work-Family Conflict and Marital Satisfaction among Working Wife}

\begin{abstract}
Marital satisfaction is an essential element for successful family life and personal growth. The women's engagement in the employment sector and their dual role as breadwinner and the care taker of family has significant correlation with the marital satisfaction. This study aimed to ascertain marital satisfaction based on demographic factors and to analyze the influences of work-family conflict on marital satisfaction. The study was a cross sectional design. Samples were selected by using non-proportional stratified random sampling technique at District of West and Central Bogor. There 120 families were randomly chosen among dual earner families in study sites. Findings showed that one of two family $(54,2 \%)$ had moderate level of work-family conflict and one of three family $(39,2 \%)$ had high level of marital satisfaction. The result confirmed that marital satisfaction was negatively influenced by work to family conflict. It means lower work to family conflict experienced by the family will higher the marital satisfaction. Demographic factor that influenced marital satisfaction was education attainment. This study is expected that family is able to organize a balancing strategy between the workplace roles and the household roles to be more satisfied about their marriage.
\end{abstract}

Keywords: dual earner, dual role, marital satisfaction, work-family conflict

\section{PENDAHULUAN}

Perkawinan merupakan salah satu tahapan yang penting dalam siklus kehidupan manusia. Pemenuhan kebutuhan dan perkembangan yang positif dalam perkawinan dapat terjadi jika hubungan antar pasangan saling melengkapi dan memuaskan. Baik suami maupun istri dapat mengalami ketidakpuasan dalam perkawinan meskipun tidak ada konflik dalam rumah tangga. Kepuasan perkawinan merefleksikan secara umum kebahagiaan dan keberfungsian dalam pernikahan seseorang (Schoen et al., 2002). Kepuasan perkawinan merupakan proses kompleks yang berlangsung sepanjang waktu, dan dipengaruhi oleh banyak 
faktor, seperti pendidikan, status sosioekonomi, cinta, komitmen, komunikasi, konflik, gender, lama pernikahan, relasi seksual, dan pembagian tugas rumah tangga (Pimentel, 2000; Trudel, 2002).

Peran istri sebagai care taker atau pemelihara rumah tangga sangat berkontribusi dalam keutuhan rumah tangga. Dewasa ini dengan adanya perubahan struktural dalam masyarakat, maka peluang bagi wanita untuk bekerja dalam berbagai bidang semakin terbuka. Seorang istri tidak hanya berperan dalam lingkungan domestik (rumah tangga), tapi juga dapat berperan di sektor publik (lingkungan kerja dan partisipasi dalam masyarakat). Berdasarkan data Sakernas (BPS, 2014), jumlah TPAK (Tingkat Partisipasi Angkatan Kerja) wanita terus meningkat dari tahun ke tahun, seperti peningkatan yang terjadi pada tahun 2012, yaitu 52,67 persen menjadi 53,26 persen pada tahun 2013. Hal ini menggambarkan pentingnya kontribusi wanita baik dalam sektor domestik dan publik.

Azeez (2013) berpendapat, bahwa peran wanita sebagai pencari nafkah dan berpartisipasi dalam dunia kerja merupakan hal yang positif dalam kesetaraan, namun juga berpengaruh pada kehidupan keluarga karena dapat menimbulkan tuntutan peran yang bertentangan. Rumah tangga dengan suamiistri bekerja (dual-earner family) menghadapi tantangan untuk memenuhi tugas dan peran di lingkungan pekerjaan maupun rumah tangga. Konflik kerja-keluarga mendapat perhatian besar dari banyak peneliti karena pengaruhnya terhadap berbagai aktifitas di tempat kerja dan rumah tangga. Pada tempat kerja, konflik kerjakeluarga mengakibatkan munculnya stres kerja dan niat pengunduran diri individu. Konflik kerja-keluarga adalah masalah bagi pegawai maupun organisasi tempat individu bekerja. Hal ini mengganggu aktifitas individu di tempat kerja dan menciptakan masalah di keluarga (Adams, King, \& King, 1996; Ghayyur \& Jamal, 2012). Masalah yang mendasar pada keluarga dengan suami dan istri bekerja adalah keterbatasan waktu untuk melakukan kewajiban, baik terhadap pekerjaan maupun keluarga.

Bila tidak terjadi keseimbangan peran istri pada tempat kerja dan rumah tangga, maka akan timbul efek negatif pada keutuhan dan komponen-komponen penting dalam rumah tangga, seperti pemenuhan kebutuhan anggota keluarga, kebahagiaan, dan perkembangan suatu keluarga (Fower \& Olson, 1993). Hal ini perlu diantisipasi, mengingat angka perceraian semakin meningkat setiap tahunnya dan 70 persen perceraian diinisiasi oleh istri (data Dirjen Bimas Islam Kementrian Agama 2010, dalam Aby, 2012). Berdasarkan pertimbangan tersebut, peneliti ingin menguji bagaimana pengaruh konflik kerja-keluarga terhadap kepuasan perkawinan keluarga pada keluarga dengan istri bekerja.

Tujuan penelitian ini adalah untuk mengidentifikasi faktor demografik, konflik kerja-keluarga dan kepuasan perkawinan pada keluarga dengan suami istri bekerja. Penelitian ini juga dilakukan untuk menganalisis hubungan faktor demografik, konflik kerja-keluarga dan kepuasan perkawinan pada keluarga dengan suami istri bekerja. Selain itu, pengaruh faktor demografik dan konflik kerja-keluarga terhadap kepuasan perkawinan pada keluarga dengan suami istri bekerja juga dianalisis dalam penelitian ini.

\section{METODE}

Penelitian ini menggunakan disain cross sectional. Pemilihan lokasi penelitian dipilih secara purposive, yaitu Kota Bogor di Kecamatan Bogor Barat (Kelurahan Pasir Jaya, Menteng, dan Cilendek Barat) dan Kecamatan Bogor Tengah (Kelurahan Paledang dan Panaragan). Pemilihan lokasi dilakukan dengan pertimbangan memiliki data kependudukan digital untuk kemudahan memperoleh data dan dilakukan pengacakan (random sampling). Penelitian dilaksanakan pada bulan Februari sampai April 2014.

Penelitian ini mengacu pada penelitian payung dengan tema suami-istri bekerja (dual earner). Populasi penelitian ini adalah keluarga dengan suami-istri bekerja yang tinggal di Kecamatan Bogor Barat dan Kecamatan Bogor Tengah. Contoh dalam penelitian ini adalah ibu bekerja. Teknik penarikan contoh dilakukan secara stratified non-proporsional random sampling berdasarkan jenis pekerjaan (formal dan informal) dengan contoh sebanyak 120 orang.

Data primer diperoleh melalui wawancara dibantu dengan kuesioner terstruktur, yang meliputi faktor demografi, konflik kerja keluarga dan kepuasan perkawinan. Faktor demografi terdiri atas usia suami-istri, pendidikan suamiistri, pendapatan keluarga, pendapatan per kapita, lama pernikahan dan jumlah anggota 
keluarga. Kategori usia suami-istri yaitu: (1) 2030 tahun, (2) 31-40 tahun, (3) 41-50 tahun, dan (4) $>50$ tahun. Kategori pendidikan suami-istri terdiri atas (1) $\leq 6$ tahun (SD), (2) 7-9 tahun (SMP), (3) 10-12 tahun (SMA), (4) 12-16 tahun (Perguruan Tinggi), dan (5) > 16 tahun (Pasca Sarjana). Pendapatan Per kapita (GK Jawa Barat, September 2012) dikategorikan (1) sangat miskin (< Rp 278.530), (2) miskin (Rp 278.530- Rp 334.236), (3) mendekati miskin (Rp 334.237- Rp 417.795) dan tidak miskin (> $\mathrm{Rp}$ 417.795). Lama pernikahan dikategorikan (1) $\leq 5$ tahun, (2) 6-10 tahun, (3) 11-20 tahun, dan (4) $>20$ tahun. Besar keluarga (BKKBN, 1998) dikategorikan (1) keluarga kecil ( $\leq 4$ orang), (2) keluarga sedang (5-7 orang), dan (3) keluarga besar ( $\geq 8$ orang).

Konflik kerja-keluarga diukur dengan menggunakan alat ukur Netemeyer, McMurrian, dan Boles (1996), yang terdiri atas dua dimensi, yaitu konflik kerja mengganggu keluarga (5 pernyataan) dan konflik keluarga mengganggu kerja (5 pernyataan). Masing-masing pernyataan dinilai dengan skala semantik (sangat tidak setuju hingga sangat setuju), dengan nilai minimal adalah 1 dan nilai maksimal adalah 4 . Nilai Cronbach's alpha untuk konflik kerjakeluarga adalah 0,855.

Kuesioner kepuasan perkawinan menggunakan alat ukur Fower dan Olson (1993), yang terdiri atas 15 pernyataan berdasarkan 10 dimensi. Masing-masing pernyataan dinilai dengan skala semantik (sangat tidak puas hingga sangat puas), dengan nilai minimal adalah 1 dan maksimal adalah 4. Nilai Cronbach's alpha untuk kuesioner kepuasan perkawinan adalah 0,877 . Sebaran contoh berdasarkan konflik kerja-keluarga dan kepuasan perkawinan dikategorikan menjadi tiga kategori berdasarkan nilai capaiannya yaitu rendah $(0,00-33,33 \%)$, sedang $(33,34-66,66 \%)$, dan tinggi $(66,67-100,00)$;

Analisis statistik yang digunakan pada penelitian ini adalah analisis deskriptif dan statistika inferensial. Analisis deskriptif digunakan untuk menggambarkan faktor demografi atau karakteristik keluarga (usia suami dan istri, pendidikan suami dan istri, pendapatan per kapita, lama pernikahan, serta jumlah anggota keluarga). Uji korelasi digunakan untuk menganalisis hubungan antara faktor demografi, konflik kerja-keluarga, dan kepuasan perkawinan. Selanjutnya, uji regresi linear berganda digunakan untuk menganalisis pengaruh faktor demografi dan konflik kerja-keluarga terhadap kepuasan perkawinan.

\section{HASIL}

\section{Faktor Demografi}

Hasil analisis pada Tabel 1 menunjukkan bahwa rata-rata usia suami berusia 38,3 tahun dan rata-rata usia istri berusia 34,9 tahun. Kelompok terbesar usia suami $(53,3 \%)$ dan istri $(56,7 \%)$ berada di kategori 31-40 tahun, yaitu usia produktif. Rata-rata lama pendidikan suami (12 tahun) dan istri (11,9 tahun) yaitu setara SMA. Rata-rata jumlah anggota keluarga adalah 4,5 orang, yaitu tergolong keluarga kecil. Rata-rata pendapatan keluarga adalah Rp6.040.000 dengan pendapatan minimum Rp600.000 dan maksimal Rp65.000.000. Menurut BPS (September 2012), batas garis kemiskinan masyarakat Kota Bogor adalah Rp278.530/kap/bulan. Rata-rata pendapatan perkapita keluarga adalah Rp1.441.000, dengan rentang minimal Rp120.000/kap/bulan dan maksimal Rp16.000.000/kap/bulan. Sebagian besar keluarga $(77,5 \%)$ tidak tergolong keluarga miskin.

\section{Konflik Kerja-Keluarga}

Konflik kerja-keluarga adalah keinginan yang berbeda atau berlawanan antara pekerjaan dengan keluarga yang mana peran yang satu menuntut lebih peran yang lain sehingga salah satunya terganggu (Netemeyer, McMurrian \& Boles, 1996). Konflik kerjakeluarga terdiri atas dua dimensi, yaitu konflik kerja mengganggu keluarga dan konflik keluarga mengganggu kerja.

Tabel 1 Sebaran keluarga ibu bekerja berdasarkan faktor demografi

\begin{tabular}{lcc}
\hline $\begin{array}{l}\text { Karakteristik } \\
\text { Keluarga }\end{array}$ & $\begin{array}{c}\text { Minimum- } \\
\text { Maksimum }\end{array}$ & $\begin{array}{c}\text { Rata-rata } \pm \\
\text { Standar } \\
\text { deviasi }\end{array}$ \\
\hline $\begin{array}{l}\text { Usia Suami } \\
\text { (tahun) }\end{array}$ & $22-56$ & $38,3 \pm 7,1$ \\
$\begin{array}{l}\text { Usia Istri (tahun) } \\
\text { Lama Pendidikan }\end{array}$ & $21-53$ & $34,9 \pm 6,5$ \\
$\begin{array}{l}\text { Suami (tahun) } \\
\text { Lama Pendidikan }\end{array}$ & $6-21$ & $12 \pm 3,5$ \\
$\begin{array}{l}\text { Istri (tahun) } \\
\text { Jumlah anggota }\end{array}$ & $6-21$ & $11,9 \pm 3,8$ \\
$\begin{array}{l}\text { keluarga (orang) } \\
\text { Lama Pernikahan }\end{array}$ & $2-10$ & $4,5 \pm 1,3$ \\
(tahun) & & $10,6 \pm 6,4$ \\
$\begin{array}{l}\text { Pendapatan } \\
\text { keluarga (Rp/bln) }\end{array}$ & $600.000-$ & $6.040 .000 \pm$ \\
$\begin{array}{l}\text { Pendapatan } \\
\text { Perkapita (Rp/bln) }\end{array}$ & $120.000-$ & 1.429 .000 \\
& 16.000 .000 & 1.827 .8000 \\
\hline
\end{tabular}


Konflik kerja mengganggu keluarga adalah konflik antar peran. Hal ini terjadi sebagai hasil dari tuntutan dan tekanan umum dari pekerjaan yang mengganggu kemampuan istri untuk melakukan tanggung jawab di keluarga. Konflik keluarga mengganggu pekerjaan adalah konflik peran akibat tuntutan umum dan ketegangan yang diciptakan oleh keluarga yang menganggu kemampuan istri untuk melakukan tanggung jawab yang berhubungan dengan pekerjaan. Tabel 2 menunjukkan bahwa satu dari dua ibu bekerja $(54,2 \%)$ tergolong memiliki konflik kerja-keluarga pada kategori sedang. Hampir separuh contoh (42,5\%) tergolong memiliki konflik kerja-keluarga rendah dan hanya sebagian kecil contoh (3,3\%) tergolong dalam konflik kerja-keluarga kategori tinggi.

Konflik kerja-keluarga yang dicapai oleh keseluruhan ibu bekerja memiliki rata-rata sebesar 51,8 persen (Tabel 3). Pada dimensi konflik kerja mengganggu keluarga menunjukkan capaian persentase ter-besar adalah pernyataan istri merasa tuntutan dari pekerjaan memengaruhi kehidupan keluarga dan rumah tangganya (58,3\%). Pada dimensi konflik keluarga mengganggu kerja menunjukkan bahwa capaian terbesar adalah pada indikator istri merasa tuntutan di rumah membuatnya sering menunda melakukan halhal di tempat kerja (52,3\%).

\section{Kepuasan Perkawinan}

Kepuasan perkawinan pada penelitian ini adalah evaluasi subjektif terhadap kualitas perkawinan secara keseluruhan (Fower \& Olson, 1993). Dimensi-dimensi dalam kepuasan perkawinan adalah masalah kepribadian (personality issues), kesetaraan peran (equalitarian roles), komunikasi (communication), penyelesaian konflik (conflict resolution), pengelolaan keuangan (financial management), aktifitas bersama (leisure activities), relasi seksual (sexual relationship), anak-anak dan perkawinan (children and marriage), keluarga dan teman (family and friends), dan orientasi keagamaan (religious orientation).

Tabel 2 Sebaran contoh berdasarkan kategori konflik kerja-keluarga

\begin{tabular}{lrr}
\hline \multirow{2}{*}{ Kategori } & \multicolumn{2}{c}{ Total } \\
\cline { 2 - 3 } & \multicolumn{1}{c}{ Jumlah } & \multicolumn{1}{c}{ Persentase } \\
\hline Rendah (0-33,3\%) & 51 & 42,5 \\
Sedang(33,4\%-66,7\%) & 65 & 54,2 \\
Tinggi $(66,8 \%-100 \%)$ & 4 & 3,3 \\
\hline Total & 120 & 100,0 \\
\hline Rata-rata \pm Standar deviasi & & $35,8 \pm 18,3$ \\
\hline
\end{tabular}

Tabel 3 Capaian konflik kerja-keluarga berdasarkan butir pernyataan

\begin{tabular}{clc}
\hline No & $\begin{array}{l}\text { Pernyataan konflik kerja } \\
\text { mengganggu keluarga }\end{array}$ & $\begin{array}{c}\text { Persentase } \\
(\%)\end{array}$ \\
\hline 1 & $\begin{array}{l}\text { Tuntutan pekerjaan } \\
\text { memengaruhi kehidupan } \\
\text { keluarga. }\end{array}$ & 58,3 \\
2 & $\begin{array}{l}\text { Jumlah waktu bekerja membuat } \\
\text { sumlitmemenuhi }\end{array}$ & 53,9
\end{tabular}

sulit memenuhi tanggung jawab dalam keluarga.

3 Kegiatan di rumah sering tidak dapat diselesaikan karena adanya tuntutan pekerjaan.

4 Pekerjaan menghasilkan tekanan yang membuat sulit untuk memenuhi tugas keluarga.

5 Tuntutan tugas pekerjaan mengharuskan membuat perubahan rencana bersama keluarga.

6 Tuntutan keluarga memengaruhi kegiatan pekerjaan.

7 Adanya tuntutan di rumah, membuat harus sering menunda dalam menyelesaikan tugas di tempat kerja.

8 Hal yang ingin dilakukan di tempat kerja tidak dapat dilakukan karena tuntutan keluarga.

9 Kehidupan keluarga mengganggu tanggung jawab di tempat kerja, seperti tidak bisa tepat waktu untuk masuk kerja dan menyelesaikan tugas sehari-hari, dan tidak bisa bekerja lembur.

10 Ketegangan yang terjadi dalam keluarga mengganggu kemampuan untuk melakukan tugas yang berhubungan dengan pekerjaan.

\begin{tabular}{ll}
\hline Rata-rata & 49,7 \\
\hline $\begin{array}{l}\text { Rata-rata total konflik kerja- } \\
\text { keluarga }\end{array}$ & 51,8 \\
\hline
\end{tabular}

Capaian kepuasan perkawinan berdasarkan butir pernyataan disajikan pada Tabel 4. Hasil yang disajikan pada Tabel 4 menunjukkan bahwa kepuasan perkawinan tinggi pada dimensi keluarga dan teman $(80,0 \%)$. Pada dimensi ini, istri merasa puas dalam hubungannya dengan orang tua, mertua, dan/atau teman. Setelah itu, dimensi kepuasan perkawinan yang memiliki persentase tertinggi kedua adalah komunikasi (communication) yaitu sebesar 77,5 persen. Pada dimensi ini, istri merasa pasangan memahami dan simpati dengan setiap perasaannya. Selain itu, istri juga merasa bahagia dengan cara komunikasi dengan pasangan. 
Tabel 4 Capaian kepuasan perkawinan berdasarkan butir pernyataan

\begin{tabular}{|c|c|}
\hline Dimensi Kepuasan Perkawinan & Persentase \\
\hline Masalah Kepribadian & 75,5 \\
\hline $\begin{array}{l}\text { Saling memahami satu sama lain } \\
\text { dengan pasangan. }\end{array}$ & 77,5 \\
\hline $\begin{array}{l}\text { Dapat menerima karakteristik } \\
\text { kepribadian dan kebiasaan } \\
\text { pasangan. }\end{array}$ & 73,5 \\
\hline Kesetaraan peran & 74,8 \\
\hline $\begin{array}{l}\text { Dapat berbagi tanggung jawab } \\
\text { peran dalam perkawinan. }\end{array}$ & 74,8 \\
\hline Komunikasi & 77,5 \\
\hline $\begin{array}{l}\text { Pasangan memahami dan simpati } \\
\text { dengan setiap "perasaan" yang } \\
\text { diungkapkan. }\end{array}$ & 73,3 \\
\hline $\begin{array}{l}\text { Bahagia dengan cara komunikasi } \\
\text { dengan pasangan. }\end{array}$ & 81,7 \\
\hline Penyelesaian Konflik & 70,9 \\
\hline $\begin{array}{l}\text { Dapat menyelesaikan konflik dengan } \\
\text { baik. }\end{array}$ & 68,9 \\
\hline $\begin{array}{l}\text { Senang dengan cara bersama dalam } \\
\text { membuat keputusan dan } \\
\text { memecahkan konflik. }\end{array}$ & 72,9 \\
\hline Pengelolaan Keuangan & 74,5 \\
\hline $\begin{array}{l}\text { Bahagia dengan posisi keuangan } \\
\text { dan cara membuat keputusan } \\
\text { keuangan bersama pasangan. }\end{array}$ & 77,1 \\
\hline $\begin{array}{l}\text { Semua kebutuhan dapat terpenuhi } \\
\text { dengan situasi keuangan saat ini. }\end{array}$ & 71,9 \\
\hline Aktifitas Bersama & 72,7 \\
\hline $\begin{array}{l}\text { Bahagia dengan cara mengatur } \\
\text { waktu luang dan waktu yang } \\
\text { digunakan bersama. }\end{array}$ & 72,7 \\
\hline Relasi seksual & 76,1 \\
\hline $\begin{array}{l}\text { Bahagia dengan cara } \\
\text { mengekspresikan kasih sayang dan } \\
\text { berhubungan seksual dengan } \\
\text { pasangan. }\end{array}$ & 76,1 \\
\hline Anak dan pernikahan & 72,5 \\
\hline $\begin{array}{l}\text { Puas dengan cara yang digunakan } \\
\text { untuk mengatasi tanggungjawab } \\
\text { sebagai orang tua }\end{array}$ & 73,1 \\
\hline $\begin{array}{l}\text { Tidak menyesalkan hubungan } \\
\text { dengan pasangan sampai saat ini. }\end{array}$ & 71,9 \\
\hline Keluarga dan Teman & 80,0 \\
\hline $\begin{array}{l}\text { Puas dengan hubungan dengan } \\
\text { orang tua, mertua, dan/atau teman. }\end{array}$ & 80,0 \\
\hline Orientasi Religius & 76,7 \\
\hline $\begin{array}{l}\text { Puas dengan cara masing-masing } \\
\text { mempraktekkan keyakinan agama } \\
\text { dan nilai-nilai. }\end{array}$ & 76,7 \\
\hline
\end{tabular}

Tabel 5 menunjukkan bahwa lebih dari separuh ibu bekerja $(60,0 \%)$ memiliki kepuasan perkawinan pada kategori sedang. Sebanyak satu dari tiga contoh $(39,2 \%)$ memiliki kepuasan perkawinan tinggi, dan sebagian kecil contoh $(0,8 \%)$ memiliki kepuasan perkawinan pada kategori rendah.
Tabel 5 Sebaran contoh berdasarkan kategori kepuasan perkawinan

\begin{tabular}{lrr}
\hline \multirow{2}{*}{ Kategori } & \multicolumn{2}{c}{ Total } \\
\cline { 2 - 3 } & Jumlah & Persentse \\
\hline Rendah $(0-33,3 \%)$ & 1 & 0,8 \\
Sedang $(33,4 \%-66,7 \%)$ & 72 & 60 \\
Tinggi $(66,8 \%-100 \%)$ & 47 & 39,2 \\
\hline Total & 120 & 100,0 \\
\hline Rata-rata \pm Standar deviasi & $66,4 \pm 14,6$ \\
\hline
\end{tabular}

\section{Hubungan Antar Peubah Penelitian}

Hasil analisis hubungan (Tabel 6) menunjukkan bahwa konflik kerja mengganggu keluarga berhubungan negatif dengan pendidikan istri, dan berhubungan positif dengan besar keluarga. Hal ini berarti semakin tinggi pendidikan istri semakin rendah konflik kerjakeluarga, dan semakin besar anggota keluarga maka semakin tinggi konflik kerja-keluarga. Konflik keluarga mengganggu kerja berhubungan positif dengan besar keluarga dan konflik kerja mengganggu keluarga, berarti semakin besar keluarga dan semakin tinggi konflik kerja mengganggu keluarga maka semakin tinggi konflik keluarga mengganggu kerja.

Kepuasan perkawinan berhubungan positif dengan pendidikan istri, dan berhubungan negatif dengan besar keluarga, lama pernikahan, konflik kerja mengganggu keluarga, dan konflik keluarga mengganggu kerja. Hal ini berarti, semakin tinggi pendidikan istri maka semakin tinggi kepuasan perkawinan. Sebaliknya, semakin besar jumlah keluarga, semakin lama pernikahan, semakin tinggi konflik kerja mengganggu keluarga dan konflik keluarga mengganggu kerja, maka semakin rendah kepuasan perkawinan.

\section{Pengaruh Faktor Demografik dan Konflik Kerja-Keluarga terhadap Kepuasan Perkawinan}

Pengaruh faktor demografi, konflik kerja, konflik keluarga terhadap kepuasan perkawinan dianalisis menggunakan uji regresi linear berganda. Model yang disusun memiliki koefisien determinasi (Adjusted $R$ Square) sebesar 0,151. Hasil ini menunjukkan 15,5 persen factor yang memengaruhi kepuasan perkawinan dapat dijelaskan oleh perubahan variabel yang ada dalam model. Sisanya yaitu sebesar 84,9 persen dipengaruhi oleh variabel yang tidak dianalisis dalam model. Koefisien regresi untuk analisis pengaruh faktor demografi, konflik kerja, konflik keluarga terhadap kepuasan perkawinan disajikan pada Tabel 7. 
Tabel 6 Koefisien korelasi antara faktor demografik, konflik kerja-keluarga, dan kepuasan perkawinan

\begin{tabular}{|c|c|c|c|c|c|c|c|c|}
\hline & $\mathrm{X} 1$ & $\mathrm{X} 2$ & X3 & $\mathrm{X} 4$ & $x 5$ & $\mathrm{X} 6$ & $\mathrm{X} 7$ & $\mathrm{X} 8$ \\
\hline $\begin{array}{l}\text { Usia istri } \\
\text { (X1) }\end{array}$ & -1 & & & & & & & \\
\hline $\begin{array}{l}\text { Pendidikan istri } \\
\text { (X2) }\end{array}$ & $-0,110$ & -1 & & & & & & \\
\hline $\begin{array}{l}\text { Besar keluarga } \\
\text { (X3) }\end{array}$ & $-0,473^{* *}$ & $-0,289^{*}$ & -1 & & & & & \\
\hline $\begin{array}{l}\text { Pendapatan } \\
\text { keluarga } \\
\text { (X4) }\end{array}$ & $-0,010$ & $-0,482^{\star *}$ & $-0,209^{*}$ & -1 & & & & \\
\hline $\begin{array}{l}\text { Lama pernikahan } \\
\text { (X5) }\end{array}$ & $-0,465^{\star *}$ & $-0,388^{* *}$ & $-0,124$ & $-0,147$ & -1 & & & \\
\hline $\begin{array}{l}\text { Konflik kerja } \\
\text { mengganggu } \\
\text { keluarga } \\
(\mathrm{X} 6)\end{array}$ & $-0,104$ & $-0,243^{*}$ & $-0,264^{*}$ & $-0,132$ & $-0,133$ & -1 & & \\
\hline $\begin{array}{l}\text { Konflik keluarga } \\
\text { mengganggu } \\
\text { kerja } \\
\text { (X7) }\end{array}$ & $-0,094$ & $-0,156$ & $-0,359^{*}$ & $-0,087$ & $-0,112$ & $-0,217^{\star}$ & -1 & \\
\hline $\begin{array}{l}\text { Kepuasan } \\
\text { perkawinan } \\
(\mathrm{X} 8)\end{array}$ & $-0,117$ & $-0,431^{* *}$ & $-0,269^{*}$ & $-0,101$ & $-0,306^{* *}$ & $-0,495^{\star *}$ & $-0,371^{*}$ & 1 \\
\hline
\end{tabular}

Tabel 7 Koefisien regresi pengaruh karakteristik demografik dan konflik kerjakeluarga terhadap kepuasan perkawinan

\begin{tabular}{|c|c|c|c|}
\hline \multirow{2}{*}{ Variabel } & \multicolumn{2}{|c|}{ Koefisien regresi } & \multirow{2}{*}{ Sig. } \\
\hline & $B$ & $\beta$ & \\
\hline Konstanta & 43,881 & & $0,000^{* *}$ \\
\hline $\begin{array}{l}\text { Usia istri } \\
\text { (tahun) }\end{array}$ & 0,190 & 0,186 & 0,210 \\
\hline $\begin{array}{l}\text { Pendidikan istri } \\
\text { (tahun) }\end{array}$ & 0,520 & 0,299 & $0,001^{* * *}$ \\
\hline $\begin{array}{l}\text { Jumlah } \\
\text { anggota } \\
\text { keluarga } \\
\text { (orang) }\end{array}$ & 0,270 & 0,576 & 0,466 \\
\hline $\begin{array}{l}\text { Pendapatan } \\
\text { keluarga (Rp) }\end{array}$ & $5,117 \mathrm{E}-8$ & 0,058 & 0,469 \\
\hline $\begin{array}{l}\text { Lama } \\
\text { pernikahan } \\
\text { (tahun) }\end{array}$ & $-0,153$ & $-0,150$ & 0,581 \\
\hline $\begin{array}{l}\text { Konflik kerja } \\
\text { mengganggu } \\
\text { keluarga }\end{array}$ & $-0,483$ & $-0,241$ & $0,006^{* * *}$ \\
\hline $\begin{array}{l}\text { Konflik } \\
\text { keluarga } \\
\text { mengganggu } \\
\text { kerja }\end{array}$ & $-0,038$ & $-0,246$ & $0,098^{*}$ \\
\hline $\mathrm{F}$ & & $8,724^{\star \star \star}$ & \\
\hline Sig. & & $0,000^{\star * \star}$ & \\
\hline R Square & & $0,183^{* \star *}$ & \\
\hline $\begin{array}{l}\text { Adjusted } R \\
\text { Square }\end{array}$ & & $0,151^{\star \star \star}$ & \\
\hline $\begin{array}{l}\text { Keterangan: } \\
\mathrm{B}=\text { Tidak terstanda } \\
3=\text { Terstandardisas }\end{array}$ & . & 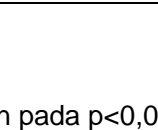 & \\
\hline
\end{tabular}

Hasil analisis regresi yang disajikan pada Tabel 7 menunjukkan bahwa kepuasan perkawinan dipengaruhi oleh pendidikan istri $(B=0,520, p<0,01)$, konflik kerja mengganggu kerja $(B=-0,483, p<0,01)$, dan konflik keluarga mengganggu kerja $(B=-0,038, p<0,1)$. Pendidikan istri berpengaruh positif terhadap kepuasan perkawinan. Hasil ini menunjukkan bahwa pertambahan lama istri dalam mengikuti pendidikan formal dapat meningkatkan kepuasan perkawinan yang dirasakan oleh istri.

Sementara itu, konflik kerja yang mengganggu keluarga berpengaruh signifikan negatif terhadap kepuasan perkawinan. Hasil ini menunjukkan bahwa kepuasan perkawinan yang dirasakan istri semakin menurun dengan bertambahnya konflik kerja yang mengganggu keluarga. Selain itu, pengaruh negatif terhadap kepuasan perkawinan yang dirasakan istri juga ditemukan pada konflik keluarga yang mengganggu kerja. Kepuasan perkawinan yang dirasakan istri menurun dengan bertambahnya konflik kerja yang mengganggu keluarga.

\section{PEMBAHASAN}

Istri bekerja dapat berkontribusi terhadap ekonomi keluarga, namun di sisi lain menimbulkan peran ganda. Peran ganda istri dapat berpengaruh terhadap keluarga. Keseimbangan peran dalam keluarga dan pekerjaan dapat memengaruhi kepuasan (Beham \& Drobnic, 2010). Hasil penelitian ini menemukan bahwa kepuasan perkawinan 
dipengaruhi oleh konflik kerja-keluarga. Istri yang dapat menangani konflik kerja-keluarga dengan baik cenderung lebih puas dengan perkawinannya.

Kebanyakan pekerja melaporkan bahwa keluarga lebih penting dari pekerjaan, dan penelitian membuktikan bahwa konflik kerja mengganggu keluarga lebih sering terjadi dibandingkan dengan konflik keluarga mengganggu kerja (Netemeyer, McMurrian dan Boles, 1996). Penelitian mengenai konflik kerjakeluarga menemukan bahwa variabel ini memengaruhi beberapa aspek, yaitu psychological well-being, depresi, kepuasan perkawinan, dan kepuasan hidup (Greenhaus \& Beutell, 1985).

Berdasarkan deskripsi konflik kerja keluarga, persentase dimensi konflik kerja mengganggu keluarga lebih besar dibandingkan dengan dimensi konflik keluarga mengganggu kerja. Hasil penelitian ini sejalan dengan Sunarti, Rizkillah, dan Muktiyah (2014), bahwa istri bekerja cenderung lebih mengalami konflik kerja mengganggu keluarga daripada konflik keluarga mengganggu kerja. Hal ini dapat terjadi bila istri lebih banyak menggunakan waktunya untuk bekerja dibandingkan dengan menghabiskan waktu bersama keluarga.

Greenhaus \& Beutell (2003) menambahkan, dibandingkan dengan orang yang lebih banyak terlibat dalam dunia kerja, orang yang lebih banyak terlibat dalam keluarga memiliki kepuasan hidup yang lebih tinggi karena adanya keterlibatan psikologis dalam mengerjakan peran di keluarga. Penelitian Puspitawati (2009) menjelaskan bahwa istri bekerja yang lebih mengutamakan pekerjaan daripada keluarga akan memiliki kecenderungan manajemen stress serta kesehatan mental yang kurang, sehingga lebih banyak menghabiskan waktu untuk melakukan kegiatan personal, seperti tidur, guna untuk melepaskan segala beban yang ditanggung oleh contoh, terutama beban pekerjaan.

Persentase dua dimensi konflik kerja keluarga berada pada kategori sedang. Hasil ini dapat diterangkan oleh penelitian Lu et al. (2006), bahwa dalam masyarakat kolektif seperti di Indonesia, pekerjaan dianggap sebagai kontribusi untuk kesejahteraan keluarga sehingga konflik keluarga mengganggu kerja (FWC) mereka juga lebih rendah dibanding masyarakat individualist, karena memandang dan memaknai hal ini sebagai kewajiban dalam keluarga.

Mengacu pada deskripsi kepuasan perkawinan, dimensi yang paling berkontribusi terhadap kepuasan perkawinan istri bekerja adalah hubungan dengan orang tua dan kerabat, serta komunikasi dengan pasangan. Hubungan dengan orang tua dan kerabat dapat menjadi salah satu koping untuk menghadapi berbagai masalah dalam perkawinan, karena keduanya memberikan dukungan dan bersedia membantu memecahkan masalah saat seseorang mengalami pemasalahan dalam perkawinan. Dengan begitu, memiliki hubungan yang mendalam dengan orang tua dan kerabat sangat berkontribusi terhadap kepuasan perkawinan (Unger, Jacobs, \& Cannon 1996). Komunikasi dalam rumah tangga dapat menjadi mediator bagi pasangan yang mengalami level konflik kerja-keluarga yang tinggi (Carroll et al., 2013). Oleh karena itu, suami-istri yang bekerja sangat penting dalam menjaga keterampilan berkomunikasi dengan pasangan, agar keutuhan rumah tangga tetap terjaga dan masing-masing merasa puas dengan perkawinannya.

Hasil uji hubungan dan pengaruh menunjukkan bahwa pendidikan istri berpengaruh secara positif terhadap kepuasan perkawinan. Hal ini sejalan dengan penelitian Glenn \& Weaver (1988), yang menjelaskan bahwa perbedaan tingkat pendidikan memengaruhi kemampuan individu dalam memenuhi kebutuhan, keinginan dan aspirasinya. Hal ini berarti semakin tinggi pendidikan individu semakin jelas wawasannya, sehingga persepsi terhadap diri dan kehidupan pernikahannya menjadi semakin baik.

Jumlah anggota keluarga berhubungan negatif terhadap kepuasan perkawinan. Hal ini sesuai dengan hasil penelitian Acock \& Demo, diacu dalam Benokraitis, 1996, bahwa pasangan yang memiliki lebih banyak anak atau anggota keluarga akan lebih banyak menghabiskan waktu untuk mengajarkan berbagai nilai-nilai dan aturan kepada anak, bertanggung jawab dan berhubungan baik dengan anggota keluarga lain. Pasangan dengan banyak anggota keluarga membutuhkan banyak waktu dan tenaga yang menyebabkan kekurangan waktu untuk bersama dan menghabiskan sedikit waktu untuk saling berkomunikasi yang dapat menurunkan kepuasan dalam perkawinan. 
Lama pernikahan berhubungan secara negatif terhadap kepuasan perkawinan. Awalawal pernikahan menjadi saksi bagaimana suatu keluarga beradaptasi terhadap masalah yang pada akhirnya mempererat hubungan antar pasangan. Pada kasus lain, awal-awal pernikahan dipenuhi kebahagiaan dan adaptasi yang baik, baru kemudian disusul dengan berbagai masalah (Azeez, 2013). Penelitian Blood dan Wolfe diacu dalam, Rybash, Roodin, dan Santrock, 1991 menemukan bahwa kepuasan pernikahan turun secara linear dari awal sampai 30 tahun pernikahan, sedangkan menurut Pineo kepuasan pernikahan berpuncak pada 5 tahun pertama pernikahan kemudian menurun sampai periode ketika anak-anak sudah menginjak remaja atau dewasa. Setelah anak meninggalkan rumah, kepuasan pernikahan meningkat tetapi tidak mencapai tahap seperti 5 tahun awal pernikahan. Pada umumnya, pasangan yang menikah akan menyesuaikan diri dengan baik dalam pernikahannya setelah 3-4 tahun pernikahan. Penyesuaian yang baik akan mendukung meningkatnya kepuasan perkawinan. Penjelasan tersebut berbeda dengan hasil penelitian Zainah et al. (2012), yang menyatakan bahwa pasangan dengan lama pernikahan lebih dari 10 tahun memiliki kepuasan yang lebih tinggi.

Penelitian-penelitian sebelumnya yang meneliti hubungan antara lama pernikahan degan kepuasan perkawinan memperlihatkan hasil yang tidak konsisten, maka masih ada halhal yang diperdebatkan dalam literatur-literatur tersebut (Clements \& Swensen, 2000). Beberapa penelitian memperlihatkan fakta mengenai perkawinan, bahwa hubungan dalam perkawinan memiliki kecenderungan untuk menurun dalam hal kepuasan selama 20 tahun pertama perkawinan. Sebagian besar pasangan yang baru menikah memiliki kepuasan perkawinan yang tinggi dan perubahanperubahan selama perjalanan perkawinan dapat menurunkan kepuasan perkawinan. Penelitian longitudinal Huston, McHale, dan Crouter (1986) menemukan penurunan kepuasan perkawinan selama awal pernikahan dan penelitian Glenn (1989) menegaskan dengan penemuan, bahwa pasangan yang menyatakan kepuasan perkawinan mereka dengan "sangat bahagia" (very happy) menunjukkan penurunan kepuasan perkawinan secara terus menerus dalam 10 sampai dengan 25 tahun perkawinan.

\section{SIMPULAN DAN SARAN}

Sebagian besar usia suami dan istri tergolong usia produktif (31-40 tahun). Ratarata pendidikan suami dan istri adalah setara SMA. Sebagian besar keluarga tergolong keluarga kecil dan rata-rata telah menikah selama 10,6 tahun. Pendapatan perkapita keluarga sebagian besar tidak tergolong dalam kategori miskin. Sebanyak satu dari dua istri $(54,2 \%)$ tergolong dalam kategori konflik kerjakeluarga sedang dan satu dari tiga istri $(39,2 \%)$ tergolong dalam kategori kepuasan perkawinan tinggi.

Konflik kerja-keluarga berhubungan negatif secara signifikan dengan pendidikan istri, dan berhubungan positif signifikan dengan besar keluarga. Kepuasan perkawinan berhubungan positif signifikan dengan pendidikan istri, dan berhubungan negatif secara signifikan dengan besar keluarga, lama pernikahan dan konflik kerja keluarga. Pendidikan istri, konflik kerja mengganggu keluarga dan konflik keluarga mengganggu kerja berpengaruh sangat signifikan terhadap kepuasan perkawinan.

Bagi keluarga diharapkan memperbanyak kegiatan bersama pasangan agar komunikasi tetap terjaga, mengurangi kebosanan, dan meregulasi konflik dalam perkawinan yang diakibatkan peran di tempat kerja. Bagi BKKBN, Lembaga Swadaya Masyarakat dan Lembaga Pendidikan agar meningkatkan sosialisasi mengenai peningkatan pendidikan dan keterampilan guna meningkatkan penghasilan keluarga, menikah di usia dewasa dan ajakan untuk menggunakan KB bagi keluarga besar. Peneliti lain diharapkan melakukan penelitian lanjutan dengan menganalisis hubungan antara konflik kerja-keluarga dengan manajemen waktu, serta meneliti konflik kerja-keluarga dan kepuasan perkawinan dari persepsi suami. Bagi pemerintah, stakeholder, dan instansi ketenagakerjaan diharapkan menyusun kebijakan yang ramah keluarga, terutama berkaitan dengan fasilitas, waktu kerja, dan pendapatan pekerja.

\section{DAFTAR PUSTAKA}

Aby. (2012, Februari 5). Perceraian di Indonesia terus meningkat. Poskota News. Diambil dari: http://poskotanews.com/ 2012/02/05/perceraian-di-indonesia-terusmeningkat. [diunduh 5 Februari 2014]. 
Adams, G. A., King, L. A., \& King, D. W. (1996). Relationships of job and family involvement, family social support and work family conflict with and life satisfaction. Journal of Applied Psychology, 81, 411-20.

Azeez, A. E. P. (2013). Employed women and marital satisfaction: a study among female nurses. International Journal of Management and Social Sciences Research (IJMSSR). 2(11).

[BPS] Badan Pusat Statistik. (2014). Keadaan Ketenagakerjaan. Jakarta, ID: Badan Pusat Statistik.

Beham, B., \& Drobnic, S. (2010). Satisfaction with work and family balance among German office workers. Journal of Managerial Psychology, 25(6), 669-689. doi:10.1108/02683941011056987.

Benokraitis, N. V. (1996). Marriage and Family Prentice Hall, Inc New Jersey.

Carroll, S. J., Hill, E. J., Yorgason, J. B., Larson, J.H., \& Sandberg, J.G. (2013). Couple communication as a mediator between work-family conflict and marital satisfaction. Contemporary Family Therapy, 35, 530-545.

Clements, R., \& Swensen, C. H. (2000). Commitment to one's spouse as a predictor of marital quality among older couple. Current Psychology, 19(2), 110120.

Fower, B. J., \& Olson, D. H. (1993). ENRICH marital satisfaction scale: a brief research and clinical tool. Journal of Family Psychology, 7(2), 176-185.

Ghayyur, M., \& Jamal, W. 2012. Work-family conflicts: a case of employees turnover intention. International Journal of Social Science and Humanity, 2(3).

Glenn, N. D., \& Weaver, C. N. (1988). The changing relationship of marital status to reperted happiness. Journal of marriage and the family, 50, 317-324.

(1989). Quantitive research on marital quality in the 1980's: A critical review. Journal of Family Issues, 20(1), 2546.

Greenhaus, J. H., \& Beutell, N. J. (1985). Sources of conflict between work and family roles. Academy of Management Review, 10, 76-88.

Collins, K. M., \& Shaw, J. D. (2003). The relation between workfamily balance and quality of life. Journal of Vocational Behavior, 63, 510-531.

Huston, T. L., McHale, S. M., \& Crouter, A. C. (1986). When the honeymoon's over: Changes in the marriage relationships over the first year. The Emerging Field of Personal Relationships, 109-132.

Johnson, D. R., \& Booth, A. (1990). Rural economic decline and marital quality: $A$ panel study on farm marriages. Family Relations, 39, 159-165.

Lu, L., Gilmour, R., Kao, S. F., \& Huang, M. T. (2006). A cross-cultural study of work/family demands, work/family conflict and wellbeing: The taiwanese vs british. Career Development International, 11(1), 9-27.

Netemeyer, R. G., McMurrian, R., \& Boles, J. S. (1996). Development and validation of work-family conflict and family-work conflict scales. Journal of Applied Psychology, 81(4), 400-410.

Pimentel, E. (2000). Just how do I love thee? Marital relations in urban China. Journal of Marriage and the Family, 62(1), 32-47.

Puspitawati, H. (2009). Pengaruh strategi penyeimbangan antara aktivitas pekerjaan dan keluarga terhadap kesejahteraan keluarga subjektif pada perempuan bekerja di Bogor: Analisis structural equation modelling. Jurnal IImu Keluarga dan Konsumen, 2(2), 111-121.

Rybash, J. W., Roodin, P. A., \& Santrock, J.W. (1991). Adult Development and Aging. 2nd edition. New York, US: Wm. C. Brown Publishers.

Schoen, R., Astone, N. M., Rothert, K., Standish, N. J., \& Kim, Y. J. (2002). Women employment, marital happiness and divorce. Social Forces, 81(2), 643662.http://dx.doi.org/10.1353/sof.2003.001 9.

Sunarti, E., Rizkillah, R., \& Muktiyah, N. T. (2014). Work family conflict, balancing work family, and wife's job satisfaction. Paper presented at International Work and Family Conference, New York. 
Trudel, G. (2002). Sexual and marital life: sesults of a survey. Journal of Sex and Marital Therapy, 28(3), 229-249. Diambil dari http"//dx.doi.org/10.1080/009262302 760328271. [diunduh 6 Februari 2014].

Unger, D. G., Jacobs, S. B., \& Cannon, C. (1996). Social support and marital satisfaction among couples coping with chronic constructive airway disease. Journal of Social and Personal Relationships, 13, 123-142. doi: $10.1177 / 0265407596131007$.

Zainah, A. Z., Nasir, R., Ruzy, S. H., \& Noraini, M. Y. (2012). Effects of demographic variables on marital satisfaction. Asian Social Science, 8(9). 